\title{
Developing a Smartphone Application Prototype as Digital Supplementary Reading Materials for the Tenth Graders for Vocational High School
}

\section{Pengembangan Prototipe Aplikasi Smartphone sebagai Materi Tambahan dalam Kelas Membaca secara Digital bagi Siswa SMK Kelas 10}

\author{
Azizatum Mu'afah*, Sintha Tresnadewi, Nova Ariani \\ Universitas Negeri Malang, Jl. Semarang No. 5 Malang, Jawa Timur, Indonesia \\ *Penulis korespondensi, Surel: azizatummuafah@gmail.com
}

Paper received: 04-02-2021; revised: 16-02-2021; accepted: 28-02-2021

\begin{abstract}
The use of technology in language learning has improved the development of educational products. Related to reading, it makes reading materials is not limited to printed-text only. The Mobile-assisted Language Learning (MALL) makes smartphones have big impact on education since it can be used as a device to access variety of technology-based learning materials. In such a way, the development of learning materials that can be accessed from a smartphone is highly needed. Thus, the need for accessible learning materials from a smartphone is crucial to students, especially during the situation where online learning must be carried out. Since students must do distance learning with teachers, smartphone application can be an additional material that can accommodate students to learn independently. The current study is conducted to develop a smartphone application prototype to support the benefit of technology to the practice of English Language Teaching in Indonesia. The R\&D model of Borg \& Gall (2003) was used to develop this digital supplementary reading material in the form of a smartphone application prototype. The first final product of this study is a smartphone application named 'Seeds' that has implemented the three-phase reading technique. Besides, it consists of three different titles of descriptive text added with different forms of reading activities. The product is also supported with additional features like pop-up glossary, re-reading, show-score, and share-score. The second product is the e-manual book in the form of .pdf where it is written in English and Indonesian.
\end{abstract}

Keywords: Mobile-assisted Language Learning (MALL), supplementary reading materials, Research \& Development

\begin{abstract}
Abstrak
Penerapan teknologi pada pembelajaran bahasa telah menciptakan perubahan pada pengembangan bahan ajar. Berkaitan dengan kemampuan membaca, hal tersebut membuat bahan bacaan tidak terbatas pada teks dalam bentuk fisik saja. Mobile-assisted Language Learning (MALL) menjadikan smartphone memiliki pengaruh yang besar pada pendidikan karena kemampuannya dalam mengakses berbagai macam bahan ajar berbasis teknologi. Hal tersebut menyebabkan pengembangan materi pembelajaran yang dapat diakses menggunakan gawai menjadi sangat dibutuhkan. Oleh karena itu, kebutuhan akan materi pembelajaran yang dapat diakses menggunakan gawai menjadi sangat penting bagi siswa. Terutama selama pembelajaran online sedang diberlakukan. Semenjak siswa diharuskan untuk melakukan pembelajaran jarak jauh, aplikasi gawai dapat dijadikan sebagai materi tambahan yang dapat memfasilitasi siswa untuk belajar secara
\end{abstract}


independen. Penelitian ini dilakukan untuk mengembangkan suatu prototype aplikasi gawai untuk mendukung manfaat teknologi pada kegiatan pengajaran Bahasa Inggris di Indonesia. Model penelitian R\&D oleh Borg \& Gall (2003) diterapkan dalam pengembangan materi tambahan membaca dalam bentuk prototype aplikasi gawai. Produk hasil penelitian yang pertama adalah aplikasi gawai bernama 'Seeds' yang telah menerapkan teknik membaca tiga fase. Selain itu, aplikasi yang dikembangkan berisi tiga judul teks deskriptif dengan berbagai bentuk kegiatan membaca. Produk tersebut juga didukung dengan fitur tambahan seperti pop-up glosarium, re-reading, showscore, dan share-score. Produk kedua adalah e-manual book dalam bentuk .pdf yang ditulis dalam Bahasa Inggris dan Bahasa Indonesia.

Kata Kunci: Mobile-assisted Language Learning (MALL), materi tambahan membaca, Research \& Development

\section{Introduction}

Technology development for education is one of the priorities for the Minister of Education and Culture of Indonesia. With the advancement of technology that makes bettercomputerized programs (software), students should be able to learn through many modes (Robinson, 1975). Since the focus skill of this study is reading, Long (2016) defines reading mode as any method or device that allows for reading comprehension. Electronic devices like laptops, tablets, or smartphones can help students to access e-books, English learning applications, or English learning websites.

Extensive studies have been carried out to explore Mobile-assisted Language Learning (MALL) or mobile learning (m-learning). Kukulska-Hulme and Shiled (2008) maintained that 'mobile learning' refers to formal and informal learning mediated via handled devices and potentially available anytime and anywhere. However, there is a debate on smartphone use for educational practice. The negative impact of smartphones for students makes some schools in Indonesia ban their students from bringing smartphones to school. However, smartphones still have a positive effect since a previous study conducted by Weng and Chen (2015) shows that students give positive feedback to smartphone applications to learn English. Besides, mobile learning can develop students' English skills (Bona, 2014; Klimova, 2018), introduce literature to learners (Setyowati, 2014), and provide exciting and interactive activities which can increase motivation (Tayan, 2017; Setyowati (2014). Therefore, mobile learning can offer an option to be implemented in the process of language learning.

As a response to the on-going development of MALL, the current study is conducted to develop a smartphone application prototype to support the benefit of technology to the practice of English Language Teaching in Indonesia. Our application is intended for vocational high school for the reason that in this type of school many study programs are offered that lead to the need for various instructional materials. Those different study programs make students have different needs and interests that would influence their motivation to learn and affect their learning (Hutchinson \& Waters, 1987). We selected reading as a targeted skill. As such, on choosing the text for the supplementary reading materials, one of the three descriptive texts chosen is related to the targeted students' study program.

Beyond a textbook, there are many options for additional materials and the latter may be crucial in the overall success of a course (Brown \& Lee, 2015). Those additional materials are called supplementary materials. Related to reading, a study conducted by Salih, et al. (2018) found that supplementary reading materials are an effective medium for learning reading. 
Furthermore, it is explained that supplementary reading materials could develop students' comprehension skills.

Since reading is the focus skill of this study, the development of a smartphone application prototype should implement the three-phase reading technique which consists of pre-reading, whilst-reading, and post-reading. There will be activities in each of the stages to help students comprehend the text. Before getting started to the pre-reading stage, there is a warm-up activity where the students are shown a picture and asked to describe what they see from the picture. Meanwhile in the pre-reading stage, readers can activate the relevant schema (Alyousef, 2006). The schema itself is a theory that allows the readers to predict what may happen from the text by relating the 'text' to the readers' background knowledge (McDonough, 2003). Furthermore, previewing the text on the pre-reading stage can also help students to explore the text features such as text title, pictures and captions, text heading, and other features (Sulistyo, 2011).

The second is whilst-reading or also called as a during-reading stage. This stage asks for students' understanding of the text. Cross-checking any unknown words or phrases from the dictionary and/or another similar phrase in construction could help students to reach their understanding (Sulistyo, 2011). Meanwhile, Tarshaei and Karbalaei (2015) stated that students should be given the opportunity to confirm their predictions on the whilst-reading stage, gather and organize information, and begin making generalizations gained from the text. In short, understanding the message from the text is the goal of this stage. Three different reading activities in the form of multiple-choice questions, drag-and-drop, true-false, short answers, and crossing wrong words are provided in the whilst-reading stage to help the students achieve their understanding.

For the post-reading stage, Brown \& Lee (2015) believed that comprehension questions are appropriate for this stage. Therefore, questions in the form of short answers are given in this stage. Besides, students are given a listening session that still talks about a descriptive text. In this session, students are asked to listen to the text and answer the questions. After the students have done the three stages, there is an explanation about the social function and the generic structure of a descriptive text. There are also two exercises followed to check students' understanding of the function and the structure of the descriptive text.

\section{Method}

The R\&D model by Borg and Gall (1983) is used for this study. The research stages start with needs analysis, product development, experts' validation, first revision, try-out, second revision, and the final product. Figure 1 shows the R\&D model being applied to this study. 


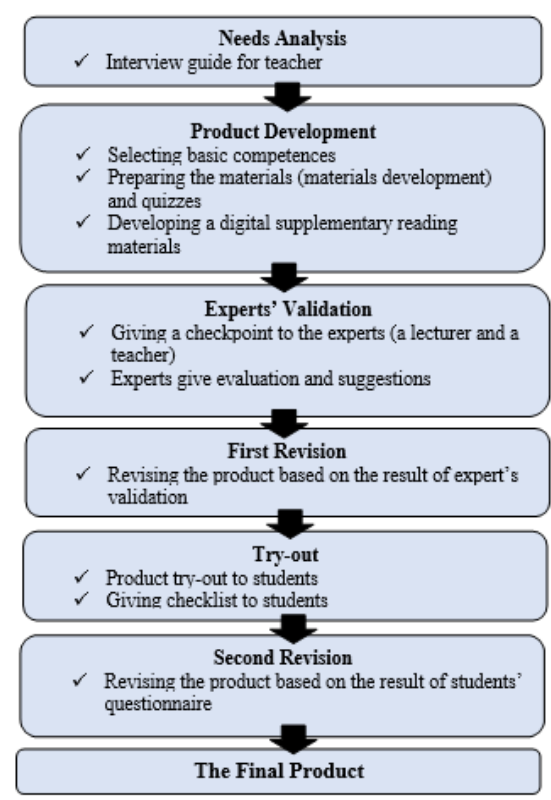

Figure 1. The Research Stages of the Study (Adopted from Borg \& Gall (1983))

The process of this research started with collecting information by conducting a needs analysis. The instrument used for this stage was an interview guide for the teacher. The interview guide was used to obtain about eight aspects related to students' characteristics, reading materials, instructional media, and MALL implementation. The result of the needs analysis will be used as the foundation for developing the product. Table 1 shows the summary of the needs analysis results and what was done by the researchers to fulfil the needs.

Table 1. The Summary of Need Analysis Results

\begin{tabular}{|c|c|c|}
\hline No & What was needed & What was done \\
\hline 1. & $\begin{array}{l}\text { Supplementary reading materials } \\
\text { which can enhance students' reading } \\
\text { motivation. }\end{array}$ & $\begin{array}{l}\text { Developing supplementary reading materials } \\
\text { which is integrated with a pop-up glossary, } \\
\text { pictures, music, and different forms of } \\
\text { activities. }\end{array}$ \\
\hline 2. & $\begin{array}{l}\text { Since the teacher only used printed } \\
\text { text while teaching reading, } \\
\text { supplementary reading materials that } \\
\text { could be accessed through } \\
\text { smartphones were suitable for this } \\
\text { online learning situation. }\end{array}$ & $\begin{array}{l}\text { Developing digital supplementary reading } \\
\text { materials in the form of a smartphone } \\
\text { application named 'Seeds.' }\end{array}$ \\
\hline 3. & $\begin{array}{l}\text { Supplementary reading materials with } \\
\text { topics related to students' study } \\
\text { program }\end{array}$ & $\begin{array}{l}\text { The two study programs in the targeted } \\
\text { schools use a meat grinder for students' } \\
\text { practicum activity. Therefore, there was a text } \\
\text { with the title 'Meat Grinder' which was } \\
\text { selected based on students' study program. }\end{array}$ \\
\hline 4. & $\begin{array}{l}\text { Reading materials that had a topic that } \\
\text { students had already known. }\end{array}$ & $\begin{array}{l}\text { From the three descriptive texts included in } \\
\text { the application, two descriptive texts were } \\
\text { selected because the students were familiar } \\
\text { with the topics. The first text was about a } \\
\text { natural tourism spot located at the students' } \\
\text { regency. The second text was about a machine } \\
\text { used when students did their practicum } \\
\text { activity. }\end{array}$ \\
\hline 5. & $\begin{array}{l}\text { Reading materials supported by a } \\
\text { glossary. }\end{array}$ & $\begin{array}{l}\text { The application was supported with a pop-up } \\
\text { glossary. }\end{array}$ \\
\hline
\end{tabular}


The second stage was analysing the result of the needs analysis as the consideration on developing the product. The product development consisted of two stages which are materials development and smartphone application development. In developing the materials, this study implements the procedure of materials development by Jolly and Bolitho (2011), consisting of exploration, contextual realization, and pedagogical realization (see Figure 2).

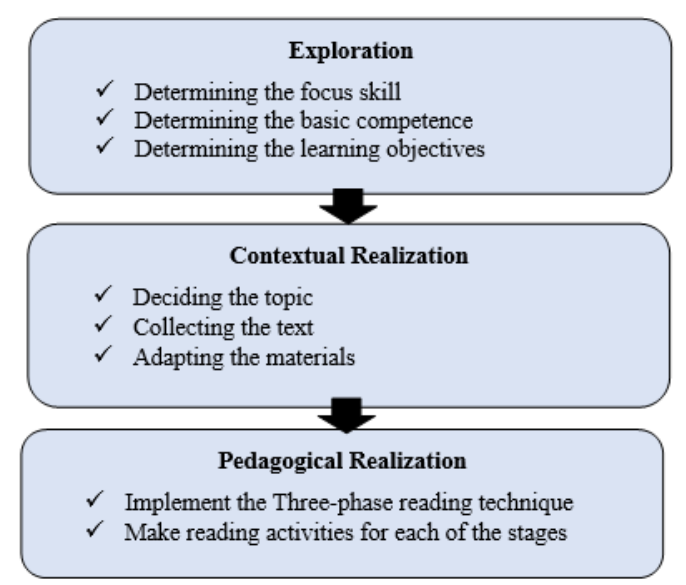

Figure 2. The Framework of Material Writing (Adapted from Jolly \& Bolitho (2011))

In the exploration stage, the researcher selected the focus skill, basic competence, and learning objectives. The focus skill of this study was reading and the basic competence used was Basic Competence 3.4 and 4.4 for the $10^{\text {th }}$ graders about Descriptive Text.

The contextual realization stage started with deciding the topic of the text. Since the targeted students of the product were Fishery students, the chosen topics were a combination of general and specific reading topics. Besides, since the basic competence stated that the descriptive text should cover the description of a place, a person, or a thing, the text chosen for the product were three descriptive texts with the title 'Ijen Crater' 'Meat Grinder' and 'Quokka'.

The pedagogical realization stage is related to the implementation of the Three-phase reading technique to the product. The Three-phase reading technique itself consists of the prereading stage, whilst-reading stage, and post-reading stage. There were reading activities made to check students' understanding of the text. Before starting with the descriptive text, there was a warm-up activity in the form of drag-and-drop. Meanwhile, on the pre-reading stage, the students showed a photo preview related to each descriptive text. Students were asked to choose the words that are suitable to describe the picture. This activity was in the form of a drag-and-drop. This activity was created to activate the students' background knowledge before reading the text. On the whilst-reading stage, the students started to read the descriptive text. There is a 'book' icon shown which has a function to reread the text. Besides, there was a pop-up glossary from some selected words from the text to help the students understand the text. After that, there were reading activities in the form of true-or-false, drag-and-drop, multiple-choice, and crossing the wrong words. Each type of activity consisted of five questions. The last was the post-reading stage in which the students were given a short listening session. The text used in the listening session was a descriptive text and the activity used was in the form of a short answer. Students should listen to the audio then answer the questions based on what they had heard. 
After the post-reading stage finished, there was an explanation about the function and generic structure of a descriptive text. There were also two activities to check students' understanding about the function and generic structure of a descriptive text. The activity about the function of the text was in the form of multiple choice. Meanwhile, the activity about the generic structure of the text was in the form of short answers and drag-and-drop. Every activity was provided with an answer key. Besides, the score of each activity appeared immediately after the students had done the activity. To help the teacher check the students' scores while using the application, the application was added with a 'Mail Result' and 'Share to WhatsApp' option in which students could share their scores. After the researcher had prepared the materials and the smartphone application concepts, she worked with a creative multimedia studio to help her develop the product.

On developing the product, the need analysis results would be the basis of making the product. Since this study needed collaborative work, the researcher worked with Makaryo Studio that has experience in developing instructional products. The studio was chosen since its portfolios showed good quality products in terms of design and animation. The researcher's role was preparing for the materials and explaining the features used for the application. The role of the creative studio was to put the researcher's concept into the product.

The next stage was asking for experts' validation. This study involved a lecturer and a teacher in validating the product. A validation sheet in the form of a checklist was used to know the product's quality. The result of the experts' validation was used as a foundation to do the first revision of the product.

The next stage is the product try-out. The product is going to be tried-out to the $10^{\text {th }}$ graders of SMKN 1 Grujugan. Since the school is still in online learning, the try-out will be conducted online. The students are going to be given three links. The first is a link to download the application, the second is a link to access the google form as an online try-out questionnaire, and the third is the link for the manual book. The links will be shared using the students' WhatsApp group, so they could get the link then join the try-out process.

After the try-out data has been obtained, the researcher revised some aspects that needed to be revised. On doing the second revision, the researcher worked with the creative studio to make a better quality of the product.

After revising the product, the final product named 'Seed' and its e-manual book was ready to be used as digital supplementary reading materials for the tenth graders of vocational high school.

\section{Findings and Discussion}

On interpreting the results of the expert's validation and the try-out, a score interpretation by Sulitsyo (2011) was used (see Table 2). If the scores obtained are above 61, the validated aspects should be revised. If the scores are above 60 , the validated aspects do not need any revision. 
Table 2. Score Interpretation adapted from Sulistyo (2011)

\begin{tabular}{|c|c|c|}
\hline \multirow{2}{*}{ Raw Score } & Score Transformation & \multirow{2}{*}{ Descriptor } \\
\hline & 100-scale & \\
\hline $81 \%-100 \%$ & $81-100$ & Very good \\
\hline $61 \%-80 \%$ & $61-80$ & Good \\
\hline $41 \%-60 \%$ & $41-60$ & Fairly good \\
\hline $21 \%-40 \%$ & $21-40$ & Not good \\
\hline $0 \%-20 \%$ & $0-20$ & Poor \\
\hline
\end{tabular}

\subsection{The Results of Experts' Validation}

The product had been validated by two experts who were a lecturer and a teacher. The first validation was done by an English teacher of SMKN 1 Grujugan on 1 October 2020. Meanwhile, the second validation was done by a lecturer of the English Department of Universitas Negeri Malang. The validation was done on 2 October 2020. The validation covered four aspects: the design and layout, program operation, content, and reading strategy (see Figure 3).

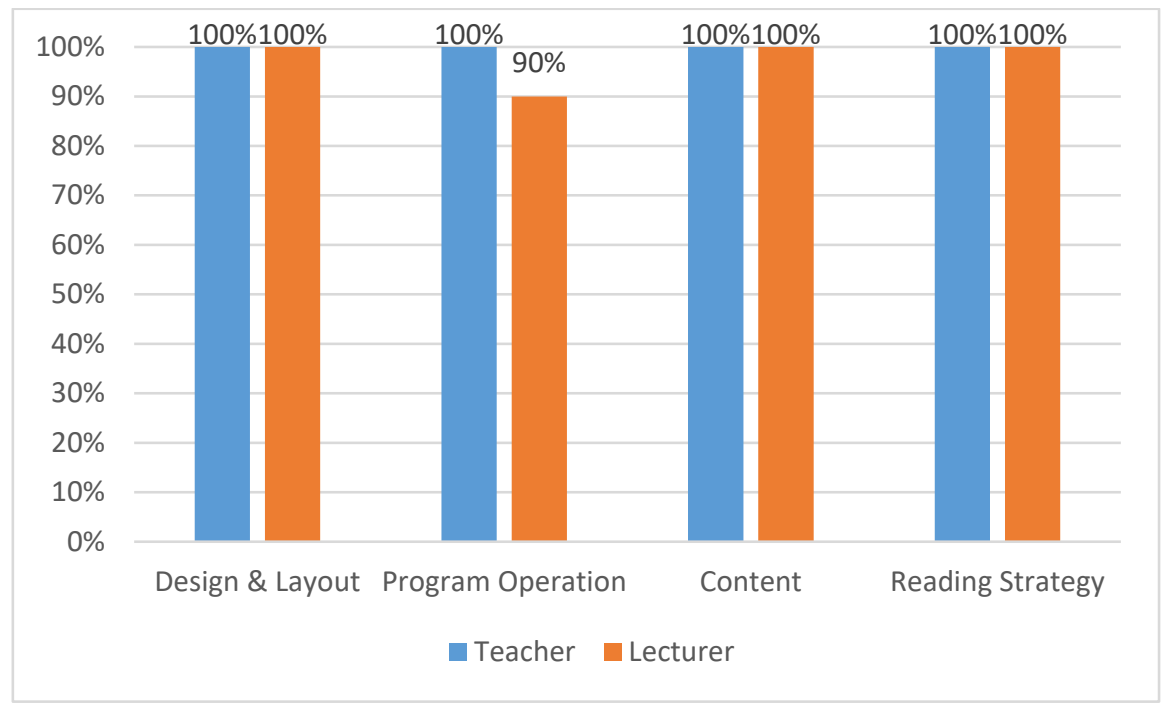

Figure 3. Results of Experts' Validation

According to the teacher, the four aspects of the application were already good. It is based on the scores gotten from each aspect that shows $100 \%$. It means that the application is very good and does not need any revisions. According to the lecturer, the design and layout, content, and reading strategy were very good. It is based on the score for each aspect that showed $100 \%$. However, the lecturer gave $90 \%$ to the program operation aspect since the user interface in every drag-and-drop activity did not run smoothly. Thus, it was a little bit hard to do the drag-and-drop activity in the application. Based on the score interpretation, $90 \%$ means that the product is still very good. However, the researcher chose to revise the user interface in the drag-and-drop activity to become smoother since it was the most used feature in the application. 


\subsection{The Results of the Product Try-out}

The try-out stage was conducted in the third week of October. It started on 20 October and ended on 27 October 2020. There were 16 participants consisting of male and female students. Since the school was in online learning, the try-out stage was done using online platforms. Those were WhatsApp and Google Form. The WhatsApp group was used to introduce and explain the application to the students, and the Google Form was used as an online checklist.

Meanwhile the try-out checklist covered three aspects. Those were the design and layout, program operation, and content (Figure 4). Based on the bar chart, $92.2 \%$ of the students agreed that the design and layout were very good. Meanwhile, $79.7 \%$ of the students agreed that the program operation and the content were already good. Therefore, the score for each aspect was above $60 \%$ and the application did not need any major revision. Each aspect has its several sub-aspects which are validated by the students. The results of sub-aspects in the design \& layout shown in Figure 5, program operation in Figure 6, and content in Figure 7.

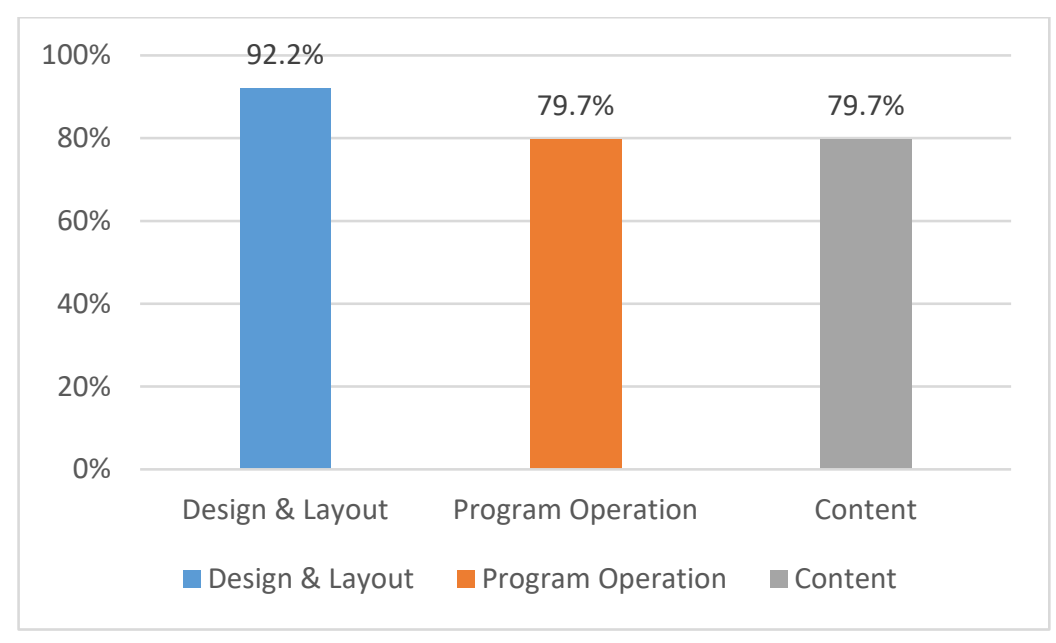

Figure 4. The Try-out Results

The first aspect was the design \& layout. There were eight validated aspects here and the mean score was $92.2 \%$. Figure 5 (see Page 8) shows the results of each aspect in the design and layout. The color choices, font and sizes, text color, layout, and icon/symbol got $100 \%$, which means that all students (16 students) thought that the application had impressive application design. Besides, the font style, the font size, and the color of the text were well-chosen and suitable. Next, the application layout was neat and different parts of the application were already labelled by icons, so it helped the students use the application. Besides, 15 students $(93.8 \%)$ agreed that the image quality used in the application was very good. The next one was the image-type suitability where 13 students $(81.3 \%)$ agreed that they were suitable for their interest. The last one was the application spacing where 10 students $(62.5 \%)$ agreed that the spacing was ideal for reading each text from the application. In short, all validated aspects in the design \& layout did not need any revisions since the score of each validated aspect was above $60 \%$ and the mean score was $92.2 \%$. 


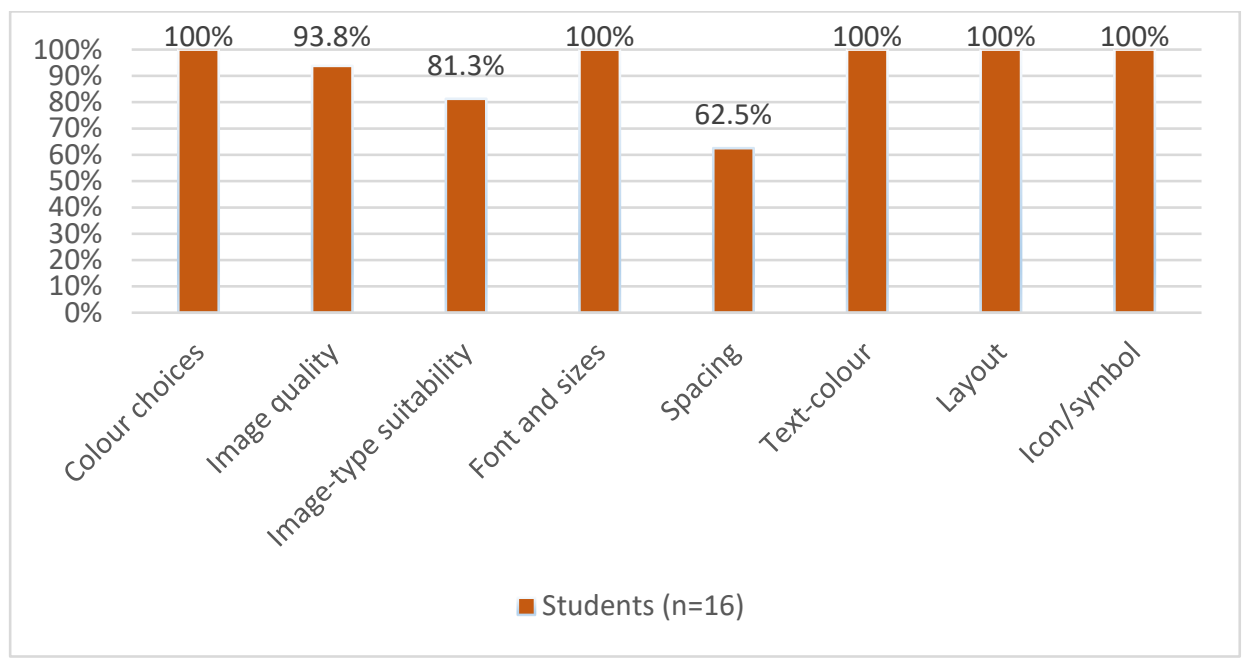

Figure 5. Try-out Results on Design \& Layout

The second aspect was the program operation where the mean score was $79.7 \%$. There were four validated aspects covered here. The results for each aspect of the program operation shown in Figure 6. First, 12 students (75\%) agreed that they could smoothly run the application. Second, 12 students (75\%) agreed that they had control over what sections to select. Third, 13 students (81.3\%) agreed that the instructions were understandable, but the rest needed additional spoken and written instructions while using the application. Forth, 14 students $(87.5 \%)$ thought that the activities provided were easy to do. In conclusion, all validated aspects in the program operation did not need any revisions because the score of each validated aspect was above $60 \%$ and the mean score was $79.7 \%$.

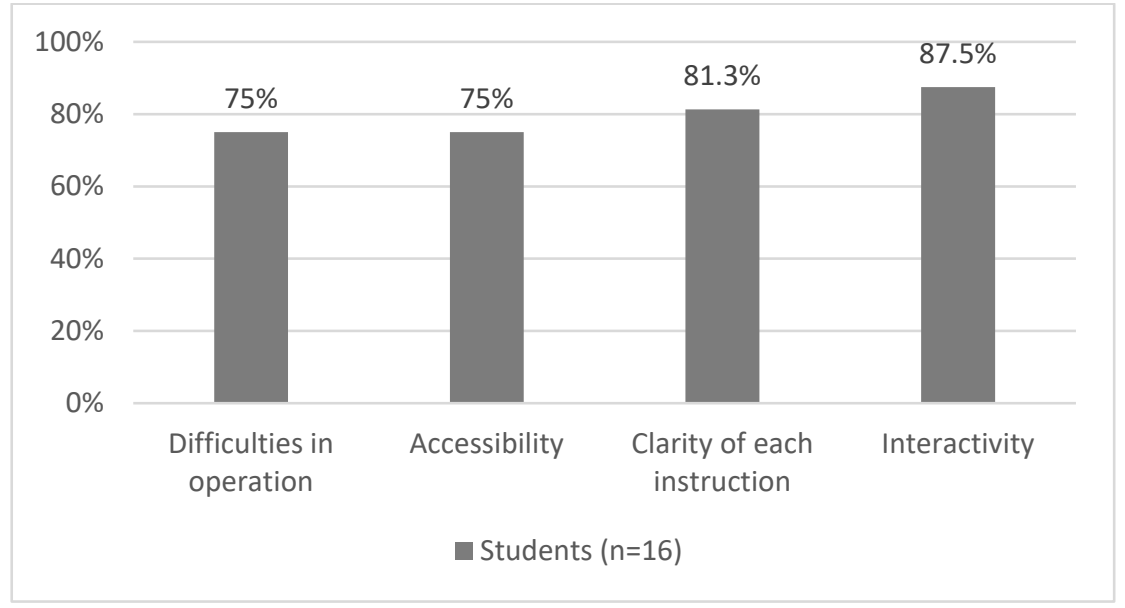

Figure 6 Try-out Results on Program Operation

The third aspect was the content of the application where the mean score was $79.7 \%$. There were six aspects being validated here. Figure 7 shows the results of each validated aspect. The topic and the illustration of the text got $100 \%$ because all students (16 students) thought the topics were interesting and the illustrations were suitable for the given text. The next one was the quiz items where 12 students (75\%) agreed that the quiz items were suitable with their English level. Moreover, 11 students (68.8\%) agreed that the reading materials, length of the text, and the pop-up glossary used in the application were suitable for them. The rest of the students thought that the materials were not ideal for them since they lacked English vocabulary, so the materials were a little bit hard for them. However, they added that if the try- 
out was conducted face-to-face, they believed that the application materials would be easier because they could ask the teacher or the researcher's explanation directly. To sum up, every validated aspect in the content of the application did not need any revisions because the score of each aspect was above $60 \%$ and the mean score was $79.7 \%$.

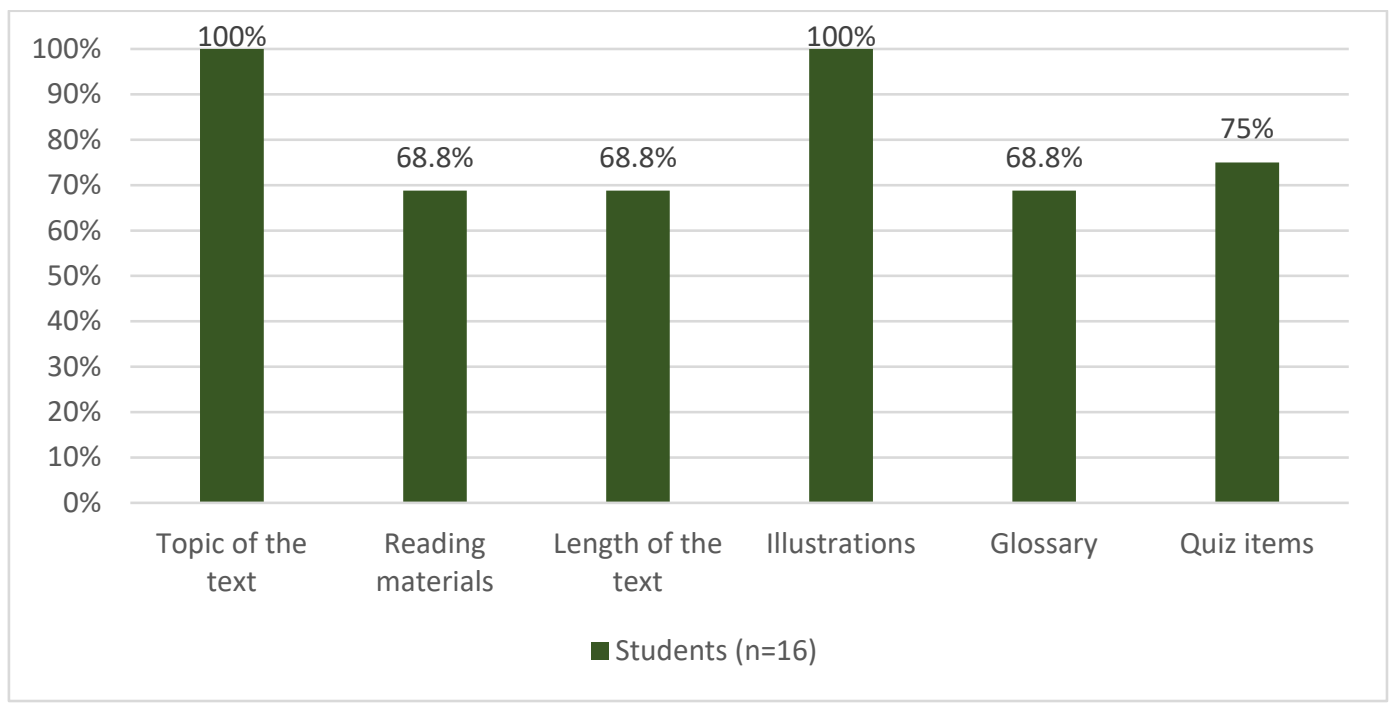

Figure 7. Try-out Results on Content

After that, four open-ended questions were given to ask about the aspects that the students liked from the application, the effect of Seeds application with students' reading interest, the difficulties in running the application, and the suggestions for the Seeds application.

There were three main reasons why students liked the Seeds application. First, there were 8 students who stated that the application could help them learn English since the materials were easy to understand. Besides, the activities provided by Seeds also helped them to understand the text. Second, 5 students liked the application because of the neat layout, pictures, and audios could make a joyful learning process. Third, 2 students said that the application was easy to operate, but 1 student added that he found difficulties while running the application since the instructions were written in English.

There were two types of answers collected to answer whether the application made the students interested in reading. 14 students said that the application had made them interested in reading since the application was easy to operate and engaging. However, 2 students said that the application did not have a significant effect on their reading interest.

On operating the application, 11 students stated that the application was easy to use. However, 2 students stated that the application was not compatible with their smartphones, so they could not run it. The other 3 students said that they lacked English vocabularies, so it was hard for them to operate or do the activities provided by the application.

Related with the comments or suggestions for the betterment of Seeds application, 10 students said that the application did not need any further revision since it was already good. Meanwhile, the other students gave their suggestions to add more pictures to the application, make the application more colorful, be consistent on the font used in the application, and provide the link and Indonesian language for the e-manual book. 


\subsection{The Final Product}

There are two final products of this study. First, a prototype of smartphone application as supplementary reading materials named Seeds (see Figure 8). The product is called a prototype since it only uses one basic competence from the curriculum. The size is 18MB and it can be run on Android-based smartphones with minimum Android version of 7.1 Nougat (API Level 25). Second, an e-manual book in the form of .pdf and the size is 1.5MB (see Figure 9). The application is already uploaded into Google Play and the link for the e-manual book was provided in the application description box. Therefore, the users can easily find and download them.

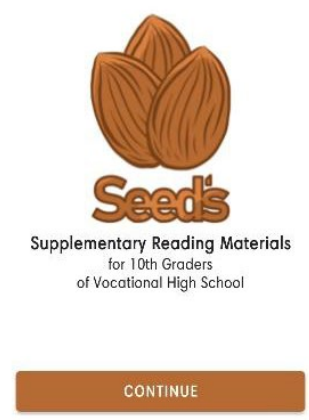

Figure 8. Seeds Application

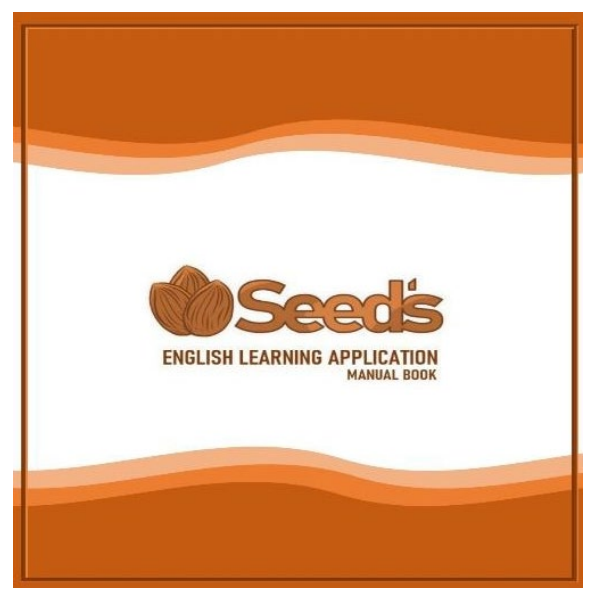

Figure 9. Seeds E-manual Book

Since the application is used as supplementary reading materials, it has implemented the three-phase reading technique including the pre-reading, whilst-reading, and post-reading stage. The application starts with the warm-up activity in the form of a drag-and-drop. After that, there will be a reading list where the students can choose one between three descriptive texts. Each text starts with the pre-reading stage in the form of drag-and-drop then continues with various forms of the whilst-reading stage activities. After that, the post-reading stage activity is in the form of short answers. After the students have done all the three-phase reading activities, there is an explanation about the social function and the text structure of a 
descriptive text. Figure 10 shows the overview of Seeds application. In addition, Seeds application is also supported with additional features like pop-up glossary, background music activation, re-reading, showing scores, and sharing scores.

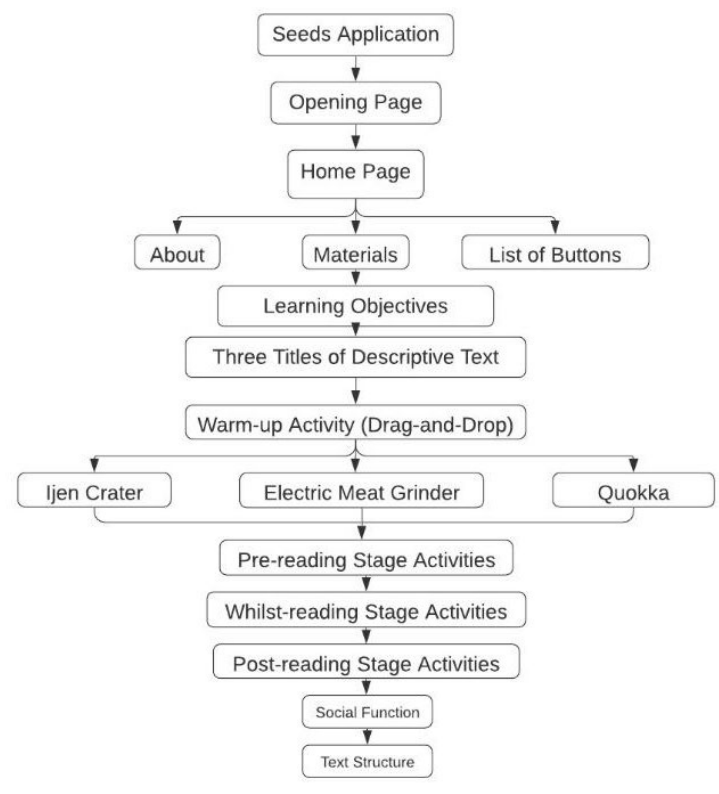

Figure 10. The Overview of Seeds Application

\section{Conclusion}

The purpose of this study is to develop a smartphone application prototype as digital supplementary reading materials for the tenth graders of vocational high school. Thus, it can be assumed that the materials or the content of the application have an important role in the significance of the product. The materials development process takes approximately about four months. The texts were selected and adapted carefully since Mukundan and Kalajahi (2016) stated that the reader's interest and background knowledge should be considered when preparing the supplementary reading materials for students. When students were given the materials that could make them interested in the lesson, it could help them learn.

The three-phase reading technique added with various reading activities were implemented into the development of the application. Types of reading activities provided from the application were multiple-choice, true-false, crossing wrong words, short answers, and drag-and-drop. The activities have varied since Setyowati (2014) stated that smartphones could create interesting and meaningful students' activities. Pictures, background music, and colorful pages were added to the application to make students feel excited while using the application. Regarding the content of the application, the study results show that almost $80 \%$ of 13 out of 16 students agree if the content is already good and suitable as their supplementary reading materials.

The smartphone application prototype has an important role in the significance of this study. There are two aspects being discussed related to the smartphone application. Those are the program operation, design, and layout of the application. Based on the result of the study, the design and layout of Seeds application got the highest score. $90 \%$ or 15 out of 16 students agree that the application design and layout are very good, making them interested in learning 
using the application. For the program operation, almost $80 \%$ or 13 out of 16 students think that the application is already easy-to-use.

Based on the try-out process, the application is found to facilitate students with their independent learning process. Starting from the try-out stage, the teacher and the researcher only guided the students to access the links. After that, the students have independently used the application. The e-manual book, showing score features and answer key, also helps the students use the application independently. A study about students' perception by Almaiah and Jalil (2014) about mobile learning implementation shows that mobile learning would enable them to learn independently. However, some students found difficulties while operating the application since it was hard for them to understand the English instructions written in the application. Therefore, there is a revision in the e-manual book where the students can read the English and Indonesian instructions.

Seeds have made reading text not limited to printed text only. The students can read the text and answer reading exercises using their smartphones. Besides, they can get the results of the exercises they have done immediately. The application contains three different descriptive texts, an explanation of the social function and text structure, and various reading activities to check students' understandings of the text. The activities were also designed in sequence from pre-reading, whilst-reading, and post-reading stages.

Last, the application can be used inside and outside the classroom and with or without an internet connection. The users only need an internet connection at the beginning when they want to download the application and use the 'share score' feature. Meanwhile, to access all the materials, they do not need any internet connection.

However, the Seeds application as the final product of this study is not without any weaknesses. First, the application can only run on Android-based smartphones with minimum Android version of 7.1 Nougat (API Level 25). If the Android version of the users' smartphones is lower than that, the application cannot be installed. Second, since the application size is 28MB and the users should download it from the Google Play Store, the storage capacity can be an issue for some users. If the storage capacity is too little, the application cannot be downloaded and installed. Third, the application cannot save the users' answers. Once the application page is accidentally force closed, the users need to fill in the answer box again.

Related to the usage of Seeds application, teachers are suggested to download and run the application first before introducing it to the students. They can install the application then be familiar with the features of Seeds. Next, teachers can read the e-manual book first to understand Seeds application. Therefore, the teachers can guide their students when facing some difficulties in using the application. Suppose there are problems downloading the application. In that case, teachers can suggest their students clean their phone storage or check the android version, whether it is compatible or not with the application.

Since Seeds application is developed based on Basic Competence 3.4 and 4.4 about Descriptive Text for the tenth graders, future researchers can develop an application based on another basic competence and for another grader. Besides, the pop-up glossary and showscore features are the main reasons the students like to use the application. Therefore, the features can be used for those who want to develop another English learning application. In addition, while developing the application, it would be better to develop an application for a 
wide range of Android versions. Seeds application can be run in minimal Android 7.1 Nougat (API level 25). Another researcher can consider developing an application that can also be operated on a smartphone with Android level below 7.1 Nougat. Although many smartphones have supported Android 7.1 Nougat or above, some smartphones have a lower level of Android 7.1 Nougat. A feature that the researcher wanted to put into Seeds application is the saveanswer feature. While developing the application, the researcher asked the programmer to put this feature to the application but failed. Therefore, once the application is force-closed, the users need to redo the activity again. As a suggestion, for the development of another learning application, one can try to use the save-answer feature to the application.

\section{References}

Almaiah, M.A., \& Jalil M.A. (2014). Investigating students' perception on mobile learning services. International Journal of Interactive Mobile Technology, 8(4), 31-36.

Alyousef, H.S. (2006). Teaching reading comprehension to ESL/EFL learners. Journal of Language and Learning 5(1), 63-73.

Bona, C. (2014). The use of Smartphone to develop English skills. The 61st TEFLIN International Conference, UNS Solo 2014 (p. 923-926). Surakarta: Sebelas Maret University.

Borg, W.R., \& Gall, M.D. (1983). Educational research: An introduction. New York: Longman.

Borg, W.R., \& Gall, M.D. (2003). Educational research: An introduction (7th Edition). New York: Longman.

Brown, H.D., \& Lee H. (2015). Teaching by principles (4 ${ }^{\text {th }}$ Edition): An interactive approach to language pedagogy. USA: Pearson.

Hutchinson, T., \& Waters, A. (1987). English for specific purposes: A learning-centred approach. Cambridge: Cambridge University Press.

Jolly, D., \& Bolitho, R. (2011). The process of materials writing. Tomlinson, B. (Ed.). Materials development and language teaching. Cambridge: Cambridge University Press.

Kukulska-Hulme, A., \& Shiled L. (2008). An overview of mobile-assisted language learning: From content delivery to supported collaboration and interaction. ReCALL, 20(3), 271-289. doi: http://dx.doi.org/doi:10.1017/S0958344008000335.

Klimova, B. (2018). Mobile phones and/or smartphones and their apps for teaching English as a foreign language. Educ Inf Technol, 23(3), 1091-1099. doi: https://doi.org/10.1007/s10639-017-9655-5.

Long, A.B. (2016). Modes of reading in the elementary classroom (Master Thesis, The College at Brockport: State University of New York). Retrieved from https://digitalcommons.brockport.edu/ehd_theses.

Mukundan, J., Zarifi, A., \& Kalajahi, S.A.R (2016). Developing reading materials for ESL learners. Issues in In Azarnoosh, et.al. (Ed.), Materials Development. Netherlands: Sense Publishers.

Robinson, H.A. (1975). Teaching reading and study strategies: The Content Areas. USA: Allyn and Bacon.

Salih, T.E.O.M., Adam, A.M.A., \& Alhafian, M.H.M. (2018). The role of teaching supplementary readers on promoting reading comprehension skills in Sudanese secondary schools students' performance. International Journal of English Research 4(6), 64-70.

Setyowati, Y. (2014). 'Mobile Comics' as a media to enhance literature's sense to young learners. The 61st TEFLIN International Conference, UNS Solo 2014 (p. 1024-1026). Surakarta: Sebelas Maret University.

Sulistyo, G.H. (2011). Reading for Meaning: Theories Teaching Strategies and Assessment. Malang: Pustaka Kaiswaran.

Tarshaei, G., \& Karbalaei, A. (2015). The effect of three phase approach on Iranian EFL learners' reading comprehension. European Journal of Natural and Social Sciences 4(2), 362-372. 
Tayan, B.M. (2017). Students and teachers' perceptions into the viability of mobile technology implementation to support language learning for first year business students in a Middle Eastern University. International Journal of Education \& Literacy Studies, 5(2), 74-83. DOI: http://dx.doi.org/10.7575/aiac.ijels.v.5n.2p.74.

Weng, T.H., \& Chen Y.J. (2015). Students' perceptions towards the use of smartphone applications for English learning. International Journal of Educational Science and Research (IJESR), 5(3), 1-10. 